\title{
TSUNAMI RISK ASSESSMENT OF SANDWIP ISLAND IN THE COAST OF BANGLADESH USING GIS TOOL
}

\author{
Zaki Uddin Ahmad ${ }^{1}$, Iftesham Bashar ${ }^{2}$, Md. Mostafizur Rahman ${ }^{3}$, Arifuzzaman ${ }^{4}$ \\ 1, 2, 3, 4 Lecturer, Department of Civil Engineering, UITS, Dhaka, Bangladesh, \\ zuahmadbuet05@gmail.com,snow_himi@yahoo.com,raazdip2020@gmail.com,arifuzzaman@uits.edu.bd
}

\begin{abstract}
The threat of tsunami on the coastal region of Bangladesh has emerged after the Great Indian Ocean earthquake in 2004. Previously, it was thought that Bangladesh is beyond the threat of tsunami but the devastating Indian Ocean tsunami has raised the need for assessing tsunami risk on Bangladesh coast, since about 32 percent of the people live in these areas. A number of geological faults have been identified in the vicinity of Bay of Bengal; which are currently being considered for potential sources of underwater earthquake. For this study, the guidelines from Intergovernmental Oceanographic Commission (IOC) is followed which includes assessing the hazard, vulnerability and final risk due to tsunami. GIS analysis was performed on the tsunami hazard map to find the ultimate risk. From the analysis it was found that a minimum of about 60 percent of people in the shelter units which are susceptible to potential inundation are at risk to lose their lives. With rise of inundation heights, the percentage of possible loss of people also rises accordingly. Again a night-time tsunami poses more threat to people than a day-time tsunami. It was focused to combine the results of hazard, vulnerability and risk assessment for a community in the coastal belt of Bangladesh.
\end{abstract}

Keywords: IOC Guidelines, Day and Night Time Tsunami, Risk Mapping

\section{INTRODUCTION}

Bangladesh is one of the countries in the world that are most prone to natural disasters. Every year the country faces various types of natural disasters like flood, tropical cyclones and subsequent storm surges, droughts, tornadoes, river bank erosion, earthquakes etc. Bangladesh is facing tremendous challenges through the last few decades against natural disaster. Such disasters cause countless ordeals to country's economic growth and affect the livelihoods of the people. Bangladesh is situated on one of the largest deltas at the confluence of second largest river systems in the world i.e. the Ganges-Brahmaputra-Meghna River system with a land area of 147,570 sq.km.

The Bangladesh coastline is about 710 kilometers long comprising of 19 districts and 147 upzilas (CZPo, 2005). The total coastal zone covers an area of 47,211 sq. $\mathrm{km}$ which is about 32 percent of the total country (Islam, 2004). 48 among 147 upzilas are directly exposed to the sea hence termed as the exposed coast while remaining 99 upzilas are considered as interior coast (Figure 1). This enormous coastal area is home to about 35.1 million people which is about 28 percent of the total population of Bangladesh with a density of 743 people per square kilometer (BBS, 2003). Among the natural disasters, recently it is predicted that, tsunamis resulting from underwater earthquake may cause severe disasters in the coastal region of Bangladesh. The lack of preparedness and appropriate warning system for tsunami has already placed this huge population in a vulnerable condition. The absence of any structural and non- structural measures to withstand tsunami provides an additional risk. The threats of disastrous Indian Ocean tsunami have emerged after the occurrence of devastating Indian Ocean tsunami on 26 December, 2004. About 300,000 people were dead in Indonesia, Thailand, India, Sri Lanka and some other countries in Asia and Africa. Bangladesh was less affected from this tsunami, but it has raised a question that whether and to what extent the country's coastal population is in potential threat due to tsunami.

Bangladesh is situated in the active plate collision zone and consequently endangered due to large magnitude of earthquakes. According to Cummins (2007), the tectonic environment at the Bay of Bengal region has similarities to other subduction zones that has experienced mega thrust earthquakes; stress and crustal strain observation indicates that the seismic zone is locked. The peril of generating tsunami along the coasts of Myanmar and Bangladesh is high due to the presence of subduction zone where one part of the Earth's crust is slowly driving under another. This active tectonic zone is situated in between the Indian plate and Myanmar plate that stretches up to Sumatra via Andaman- Nicobar zone of severe seismicity. The Sitakundu- Teknaf fault that runs along the Chittagong- Cox's Bazar coastline recommends a seismic gap which is alarming for Bangladesh coast to Tsunami (Sarker, 2008). The vicious 'locked- thrust' fault, of the kind that unleashes tsunamis runs parallel to the shore in the similar fashion to the Sumatra fault, which caused the one of the devastating tsunami on 26 December, 2004 killing about 
300,000 people. The zone is locked for about 250 years when a massive earthquake hit the region on 2 April, 1762 which also caused tsunami. The 200 kilometers long continental shelf is also said to be susceptible to earthquakes and landslides along its margins are extremely potential from generation of local tsunami.

\section{STUDIES ON TSUNAMI AND RISK ASSESSMENT OF TSUNAMI}

Since Bangladesh was less affected by tsunami in the past it was thought that the country is out of danger of being affected by tsunami in a large scale. But the 2004 Indian Ocean tsunami has drawn the attention of administration. Therefore, a few studies are carried out to assess the tsunami hazard on Bangladesh coast.

CDMP carried out several more studies as a part of National Disaster Management Policy in 2008 and assessed the progress of this policy in a quarterly basis. The tsunami relevant tasks in the policy were: i) Taking plans to provide guidelines to face natural disasters ii) Management plans for earthquakes and tsunamis iii) Preparation of hazard map for earthquakes and tsunamis.

The Quarterly Progress Report of CDMP for April- June 2009 suggested: i) Preparation of tsunami hazard map using modeling technique ii) Predicting the impact due to tsunami on Bangladesh coast iii) Determination of potential risk zone in Bangladesh iv) Updating current information on cyclone shelters as a measure of tsunami preparedness v) Identify vulnerable schools, hospitals, emergency response and control buildings in coastal region and evaluate the adaptation vi) Economic risk analysis in the coastal region due to tsunami inundation. Considering the state of tsunami vulnerability and seismic activity the Geological Survey of Bangladesh divided the country's coastal belt into three zones which is mentioned in the National Plan for Disaster Management by Disaster Management Bureau (DMB, 2008). The zones are:

Tsunami Vulnerable Zone I: Chittagong- Teknaf coastline (Most vulnerable)

Tsunami Vulnerable Zone II: Sunderbans- Barisal coastline (Moderately vulnerable)

Tsunami Vulnerable Zone III: Barisal- Sandwip Estuarine coastline (Low Vulnerable)

Sarker (2008), in his study aimed to assess tsunami hazard on Bangladesh to estimate tsunami heights as well as tsunami arrival times considering three tsunami source models. The models are the 2004 Sumatra earthquake (Magnitude 9.1) and two other scenario earthquakes (Magnitude 8.0 and 8.5). The major findings of the study included the arrival time of tsunami at the Bangladesh coast for 2004 Sumatra earthquake was 2.2 hours after its generation and the maximum inundation height of 31 centimeters at St. Martin's Island. IWM has performed another study in 2008 and prepared tsunami inundation map for Bangladesh coast. The map was prepared considering 11 potential sources of earthquakes in the Bay of Bengal. This map shows that tsunami inundation may reach up to 5 meters at the Sunderbans region and some regions near Hatiya and Nijhum Dwip. The ChittagongTeknaf coastline also found to be in risk of probable inundation from tsunami.

Mardiatno et. al., (2008), used GIS tool for tsunami risk assessment in Cilacap, South Java, Indonesia. It applied the integration of spatial data from TUNAMI model output as tsunami hazard potential and the relevant geo- database, i.e. build up area, population, productive land and selected mobile assets in Cilacap city. A number of GIS operation such as intersect, identity, dissolve and union were utilized to do the analysis. The output of this research was the tsunami risk map and the estimation of fatalities with regard to the worst case scenario of tsunami.

\section{STUDY AREA (SANDWIP ISLAND)}

The study area was selected from the potential tsunami inundation map prepared by IWM. This map was prepared with the help of another map showing the geologic faults in the Bay of Bengal which are susceptible for creating high magnitude underwater earthquakes. Underwater earthquakes are the main reasons of creating tsunamis which eventually travels along the sea, increasing in the wave height and hit the coasts. There are about 11 potential sources of underwater earthquakes in the Bay of Bengal (Figure 2). There are some geologic faults which are very close to Bangladesh coast ( $\mathrm{S}-1$, S-3, S-4, S-5 and S-8) where there are a few past evidences of creating earthquakes (represented by dots in the map). It is suspected that a massive earthquake may hit this region since both the Indian and Andaman plates are in motion at a rate of 4 to $5 \mathrm{~cm} / \mathrm{yr}$.

From the above map, considering these 11 potential sources of underwater earthquakes, a tsunami inundation map was prepared by IWM for Bangladesh coast (Figure 3). This map suggests that tsunami waves may rise as high as 4 meters in some regions. The East- West coast is susceptible region for tsunami waves reaching such heights. Most of this region is covered by the Sunderbans, largest mangrove forest in the world. For this study Sandwip Upazila of the Chittagong district is selected. Sandwip is an island along the southeastern coast of Bangladesh. It is situated at the estuary of the Meghna River on the Bay of Bengal and separated from the Chittagong coast by the Sandwip channel (Figure 4). Sandwip is a historical island of Bangladesh. It is located at the north-eastern side of The Bay of Bengal, nearby the main port city of Chittagong. It is one of the most ancient islands of Bangladesh. As of 2001 Bangladesh census, Sandwip has a population of 292,773 . Males constitute are $48.93 \%$ of the population, and females $51.07 \%$. Sandwip has an average literacy rate of $46.15 \%$ (7+ years). 


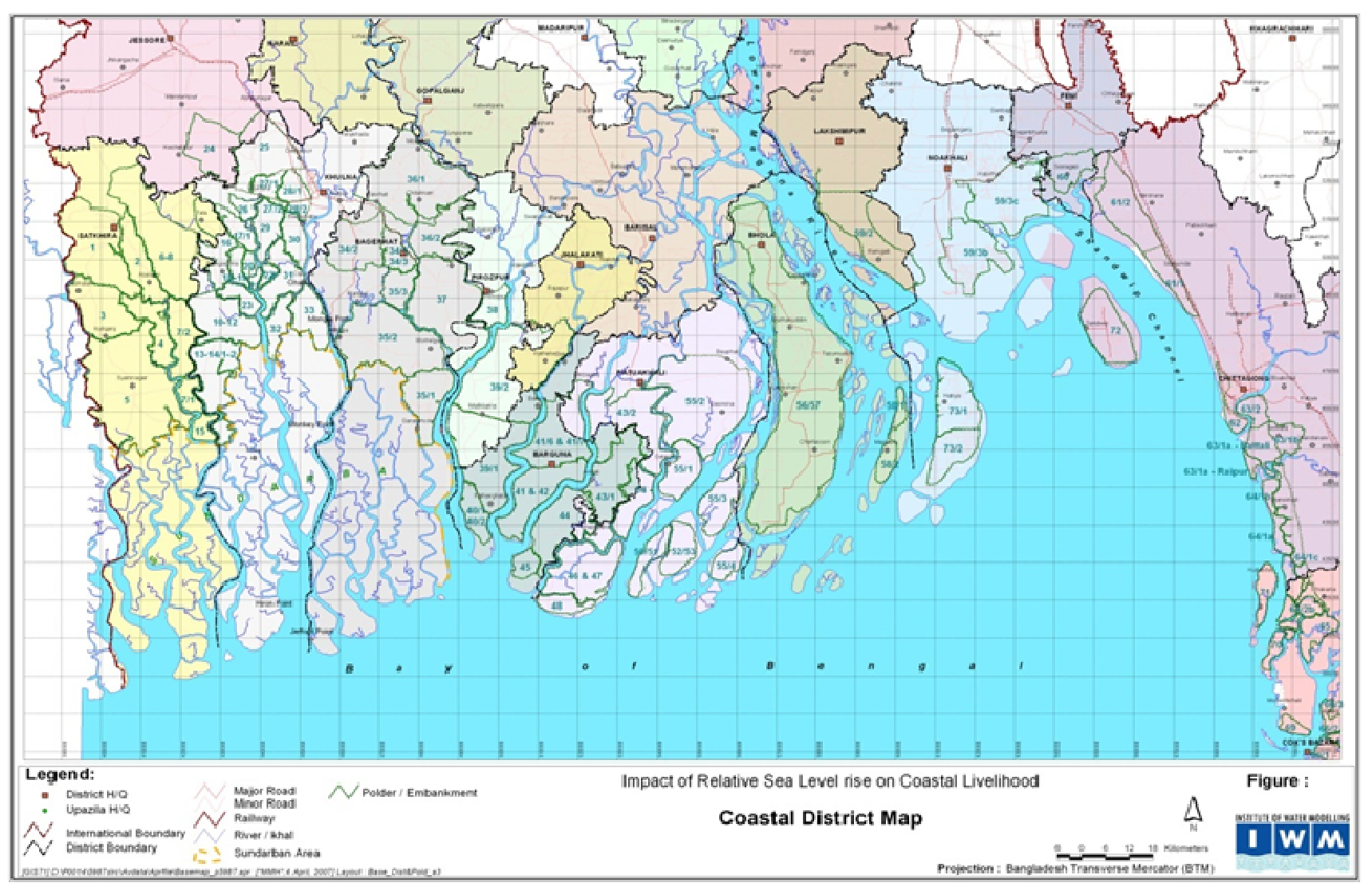

Fig -1: Coastal Zone Map of Bangladesh (Source: IWM, 2008)

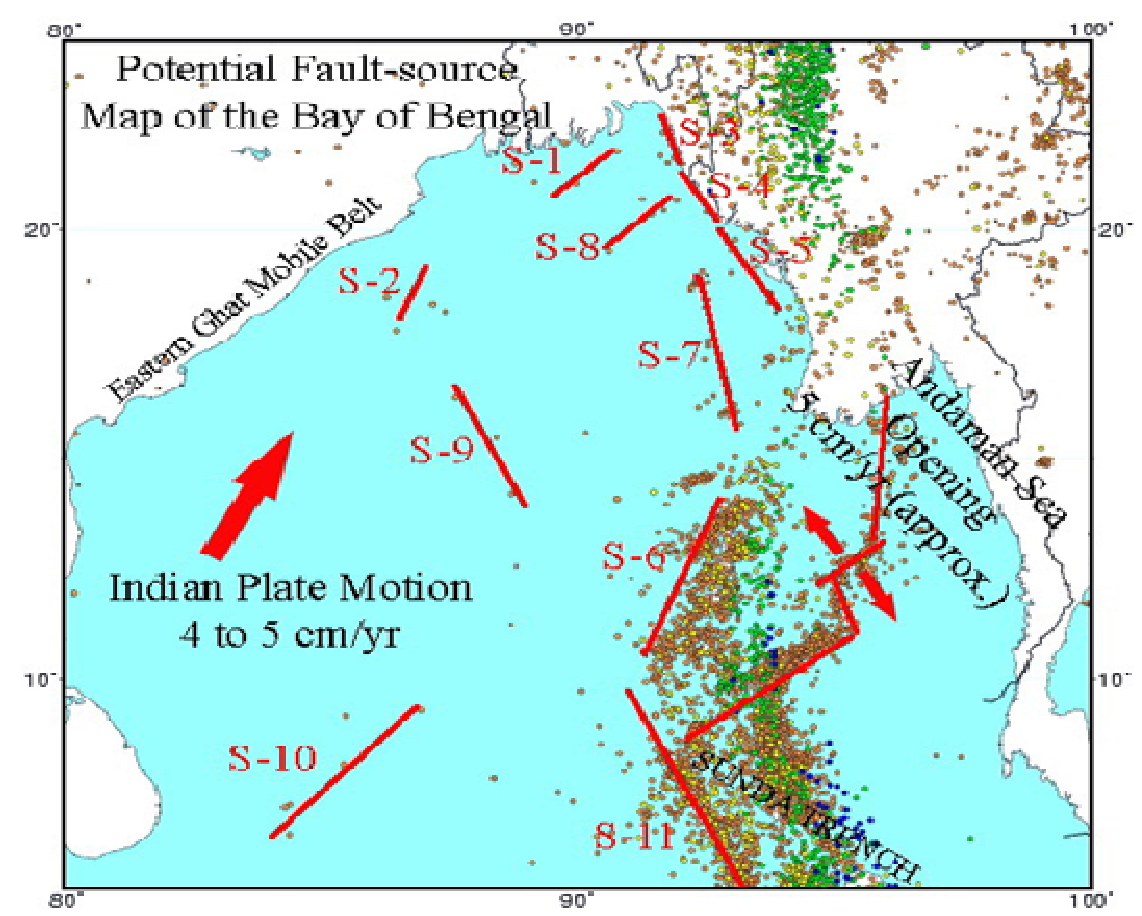

Fig-2: Potential fault sources for earthquake and tsunami in the Bay of Bengal (Source: IWM, 2008) 


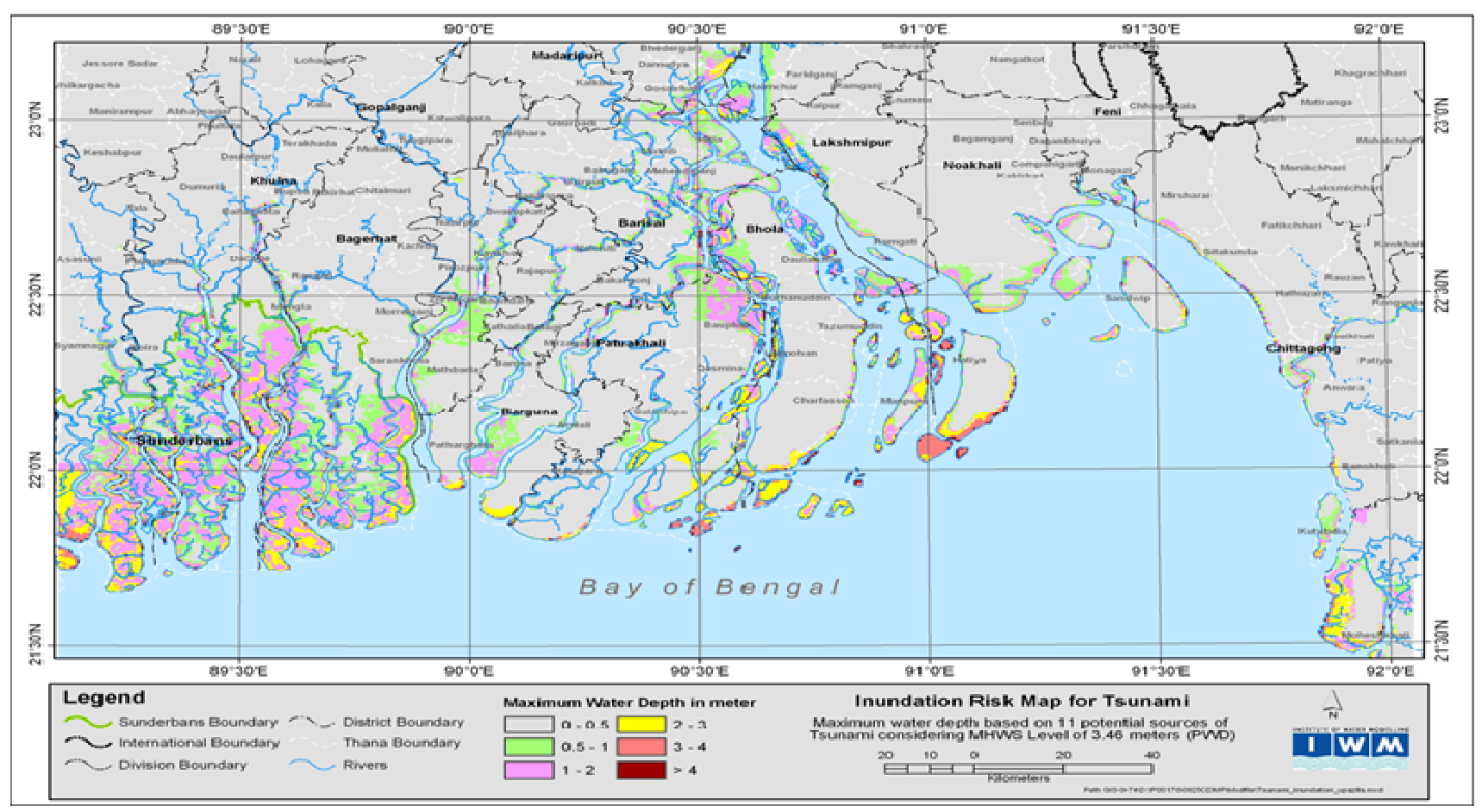

Fig-3: Inundation Risk Map for Tsunami based on 11 potential sources in the Bay of Bengal considering MHWS Level of 3.46 meter (PWD) (Source: IWM, 2008)

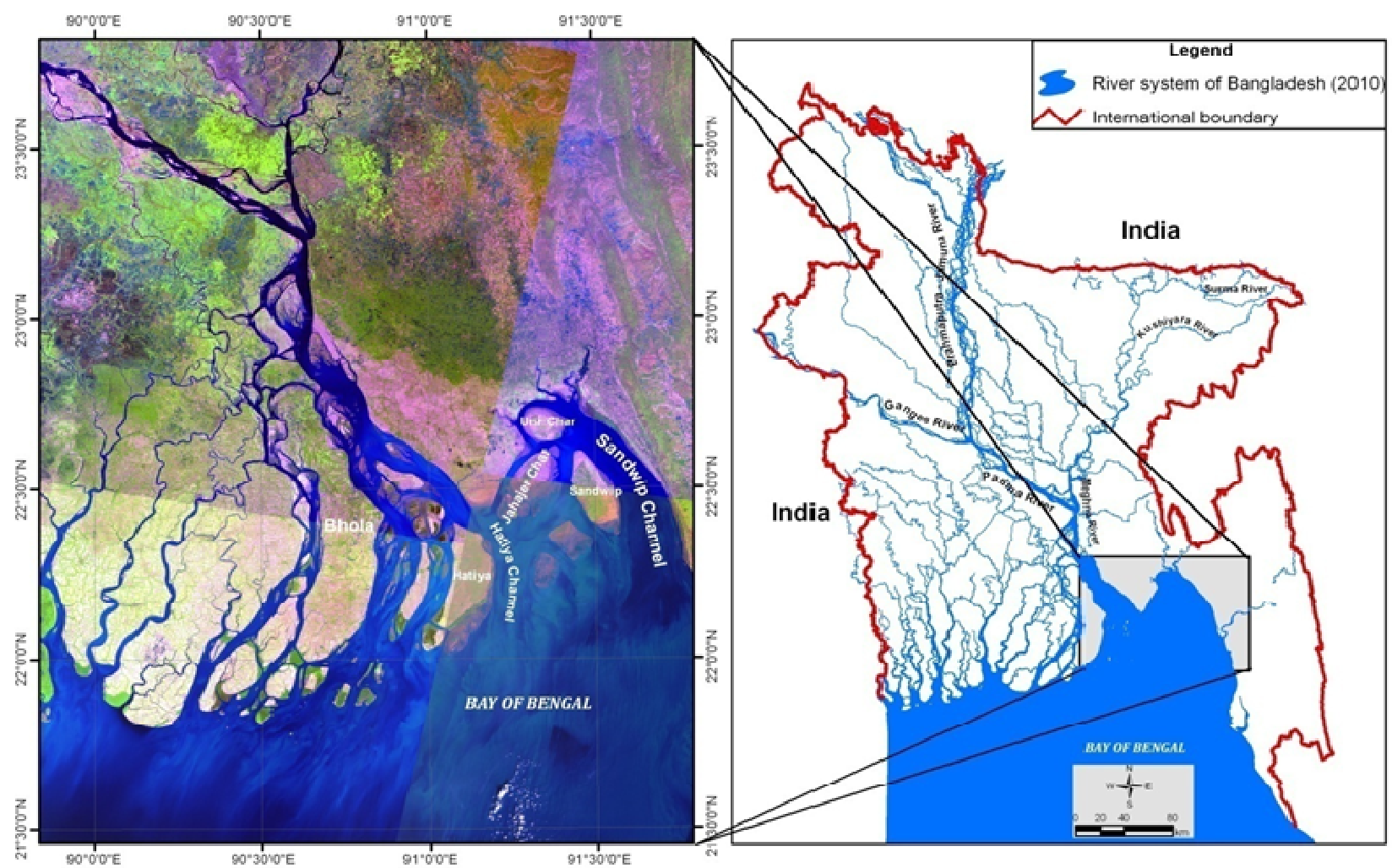

Fig- 4: Satellite Image of Landsat TM 2010 showing Sandwip Island in the Meghna Estuary 


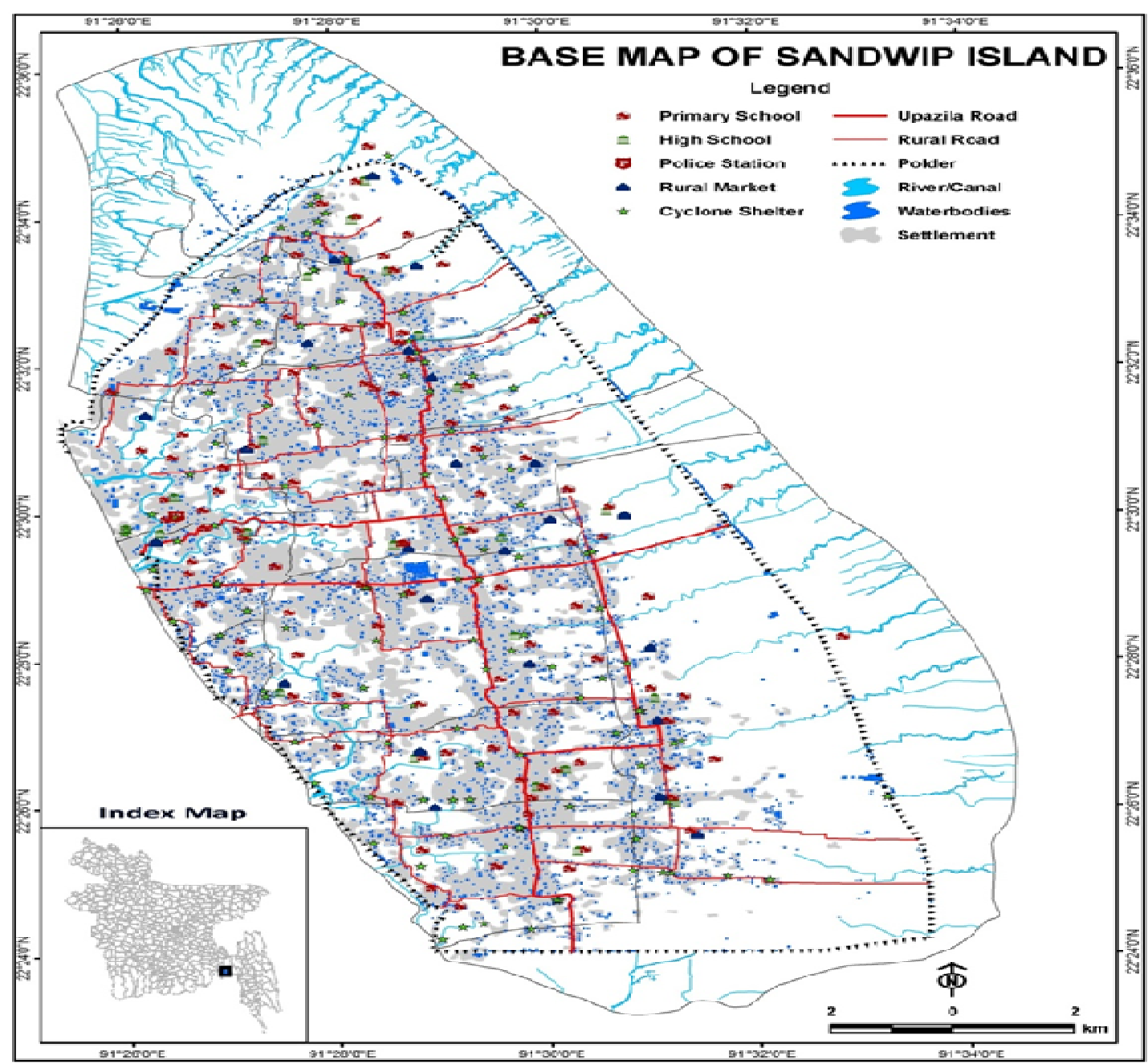

Fig- 5: Base Map of Sandwip Island

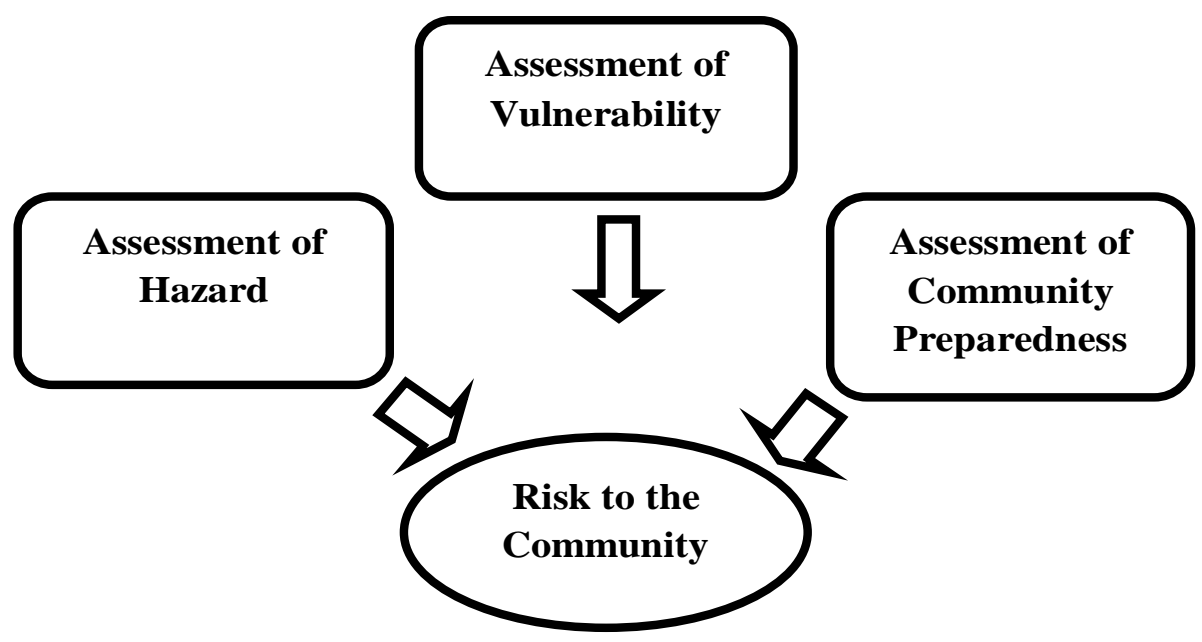

Fig- 6: Process of Risk Assessment (IOC, 2009) 


\section{METHODOLOGY OF THE STUDY}

For this study, the risk assessment of Sandwip Upazila, under Chittagong district, the IOC guidelines has been followed. According to IOC (Intergovernmental Oceanographic Commission, 2009) the process of risk assessment involves few steps for determining tsunami risk for a community. These steps are the assessment of hazard, assessment of vulnerability, assessment of community preparedness and finally the assessment of risk. The Geographic Information System (GIS) tool is used to perform the assessment. ArcGIS 10.0 software is used as a GIS tool. The process can be described by a simple diagram.

The assessment of hazard is performed based on the map showing the potential tsunami inundation at Sandwip Island provided by IWM. The map shows that tsunami ranges from 0.5 meters to 4.0 meters in the various places of the island. The tasks performed in the process are determining the geographical extent of the inundation and calculating the geographical extent of each range of inundation. The assessment of vulnerability to various social and economic infrastructures due to tsunami inundation was performed next. Firstly, an asset inventory map was prepared using geographically referenced database and then the exposure of the infrastructures to tsunami inundation was determined by overlaying the asset inventory map on the inundation map using GIS tool. In this study, these infrastructures are termed as shelter unit types for people.

In the assessment of community response, the task was performed on the community who are likely the receptors of tsunami hazard in the different shelter units. If a tsunami is generated in the Bay of Bengal due to earthquakes from the 11 potential sources, it will travel fast to reach the coast of Bangladesh and people will get little or no time to evacuate from their shelter units. Community responses are assessed considering tsunami events at daytime and night time separately because percentage of loss will be more in an event of tsunami during night time than in daytime. The tasks performed in this process are:

i. Calculating the number of people in each type of shelter unit from the demographic data. These values are assumed for each union in the Upazila except for households because the average number of people in each household varies in each union.

ii. Assigning the percentage of losses in each type of shelter unit based on their capability to endure tsunami waves at day-time and night-time i.e. the loss of people in the 'Kutcha house' are more than people in concrete buildings such as cyclone shelters, educational and administrative institutions, police stations or banks. Again, for a particular type of shelter unit loss of people during a night-time tsunami is more than a day-time tsunami. iii. Calculating total number of people exposed in the particular type of shelter units by multiplying the number of shelter unit exposed to inundation with number of people per shelter unit. That is,

Total People Exposed $=$ Number of Shelter Unit Exposed * People per Unit.

iv. Calculating the aggregated loss by percentage of loss for each type of shelter unit. That is,

Aggregated Loss $=$ Total People Exposed $*$ Percentage of Loss

v. Calculating the sums of total people exposed and aggregated loss for each type of shelter unit.

The final outcome of the risk assessment is the determination of total percentage of loss due to a tsunami and hence determining the level of risks of particular area i.e. union. Risks maps are produced using GIS tools showing the unions of Sandwip Upazila based on their risk. The total percentage of loss is calculated by,

\section{Percentage of Total Loss $=\left(\sum\right.$ Aggregated Loss $/ \sum$ Total People Exposed) * 100}

The final outcome of this process are risk maps showing different unions of Sandwip Upazila based on their risk levels due to day-time and night-time tsunami in separate maps.

\section{RESULTS AND DISCUSSIONS}

\subsection{Results of Assessment of Hazard}

Using GIS tool and geographically referenced database, the assessment of hazard was performed. The main objective of the hazard assessment was to assess the geographical extent of the inundation pattern in the Sandwip Island. Each range of inundation in the area was digitized and categorized into two types: inundation below or equal to $0.5 \mathrm{~m}$ and inundation higher than $0.5 \mathrm{~m}$ ( 0.5 to 4 meters). From GIS analysis of the inundation map, the area inundated in different unions was calculated. Highest submergence occurs in Magdhara union while lowest submergence occurs in Amanullah union. Magdhara union is the largest union in Sandwip Upazila and the extent of inundation in terms of area in this union is also highest among all other unions of this Upazila.

\subsection{Results of Assessment of Vulnerability}

Assessment of vulnerability is performed to create an asset inventory which contains a list of all infrastructures located in the study area. GIS is a key component for creating asset inventory map. With the help of geographically referenced database, assets are pointed out in the map. These assets are considered as shelter units for people living in that area. The assets are listed in the following table and also shown in the Figure 8. 


\subsection{Results of Assessment of Community Response}

Assessment of community response of the receptors of the tsunami hazard is an important part in the process of risk assessment. Since people will hardly get any time to evacuate during tsunami if it is generated in the Bay of Bengal, they will face tsunami wave at their current shelter places.

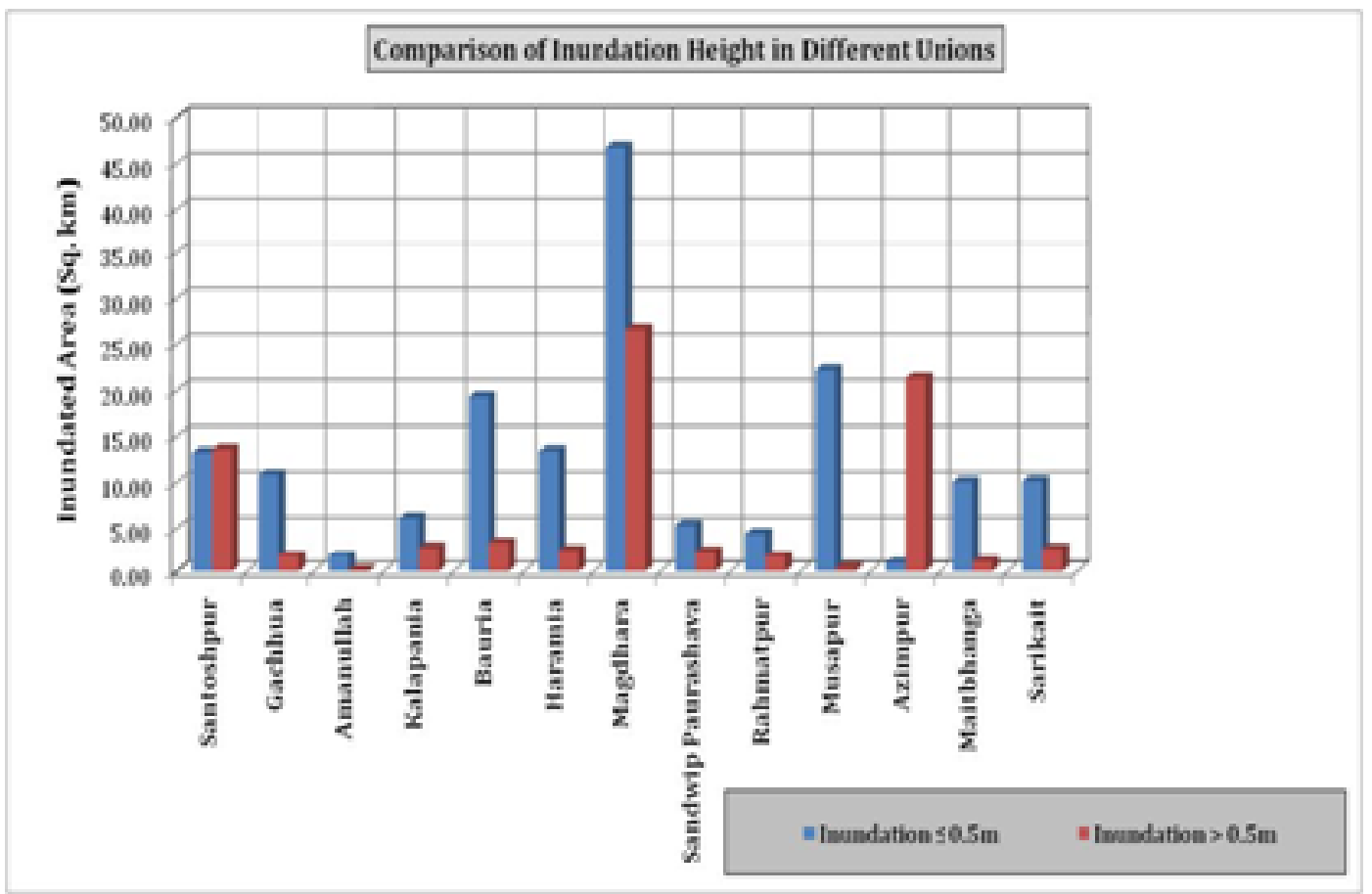

Fig-7: Comparison of Inundation Heights for Different Unions and Sandwip Upazila

Table -1: Asset Inventory of Sandwip Upazila

\begin{tabular}{|c|c|c|c|c|c|c|c|c|}
\hline $\begin{array}{l}\text { Upazila } \\
\text { Name }\end{array}$ & Union Name & $\begin{array}{l}\text { Road } \\
(\mathbf{m})\end{array}$ & $\begin{array}{c}\text { Embankment } \\
\text { (m) }\end{array}$ & $\begin{array}{l}\text { Cyclone } \\
\text { Shelter }\end{array}$ & $\begin{array}{c}\text { Primary } \\
\text { \& High } \\
\text { School }\end{array}$ & College & $\begin{array}{l}\text { Mosque/ } \\
\text { Madrasa }\end{array}$ & $\begin{array}{c}\text { Rural } \\
\text { Market }\end{array}$ \\
\hline \multirow{13}{*}{ Sandwip } & Amanullah & 1226 & 578 & 1 & 0 & 0 & 0 & 0 \\
\hline & Azimpur & 3179 & 491 & 3 & 2 & 0 & 0 & 0 \\
\hline & Bauria & 21975 & 2833 & 16 & 18 & 1 & 1 & 1 \\
\hline & Gachhua & 8311 & 4612 & 8 & 11 & 0 & 2 & 2 \\
\hline & Haramia & 13861 & 1309 & 9 & 10 & 0 & 4 & 5 \\
\hline & Kalapania & 6490 & 3371 & 8 & 6 & 0 & 1 & 0 \\
\hline & Magdhara & 24356 & 18641 & 17 & 16 & 0 & 5 & 5 \\
\hline & Maitbhanga & 9690 & 0 & 11 & 15 & 1 & 1 & 2 \\
\hline & Musapur & 20229 & 0 & 21 & 15 & 0 & 3 & 3 \\
\hline & Rahmatpur & 9006 & 2461 & 9 & 10 & 1 & 3 & 1 \\
\hline & Paurashava & 4754 & 0 & 7 & 10 & 0 & 2 & 1 \\
\hline & \begin{tabular}{|l|} 
Santoshpur \\
\end{tabular} & 3095 & 6117 & 9 & 9 & 0 & 2 & 2 \\
\hline & Sarikait & 14303 & 3431 & 15 & 8 & & 3 & 0 \\
\hline \multicolumn{2}{|c|}{ Total } & 140476 & 43844 & 134 & 130 & 3 & 27 & 22 \\
\hline
\end{tabular}




\begin{tabular}{|c|c|c|c|c|c|c|}
\hline $\begin{array}{l}\text { Upazila } \\
\text { Name }\end{array}$ & Union Name & $\begin{array}{c}\text { Family Welfare } \\
\text { Centre }\end{array}$ & Hospital & Food Go down & $\begin{array}{l}\text { Ferry } \\
\text { Ghat }\end{array}$ & Deep Tubewells \\
\hline \multirow{11}{*}{ Sandwip } & Amanullah & 0 & 0 & 0 & 0 & 1 \\
\hline & Bauria & 0 & 0 & 0 & 0 & 1 \\
\hline & Gachhua & 0 & 1 & 0 & 0 & 0 \\
\hline & Haramia & 0 & 0 & 1 & 0 & 3 \\
\hline & Kalapania & 0 & 1 & 0 & 1 & 1 \\
\hline & Magdhara & 0 & 0 & 0 & 0 & 1 \\
\hline & Maitbhanga & 1 & 0 & 1 & 0 & 0 \\
\hline & Musapur & 1 & 0 & 0 & 0 & 0 \\
\hline & Rahmatpur & 1 & 0 & 0 & 1 & 0 \\
\hline & Paurashava & 1 & 1 & 0 & 1 & 1 \\
\hline & Santoshpur & 0 & 0 & 0 & 1 & 2 \\
\hline \multicolumn{2}{|c|}{ Total } & 4 & 3 & 2 & 4 & 10 \\
\hline
\end{tabular}

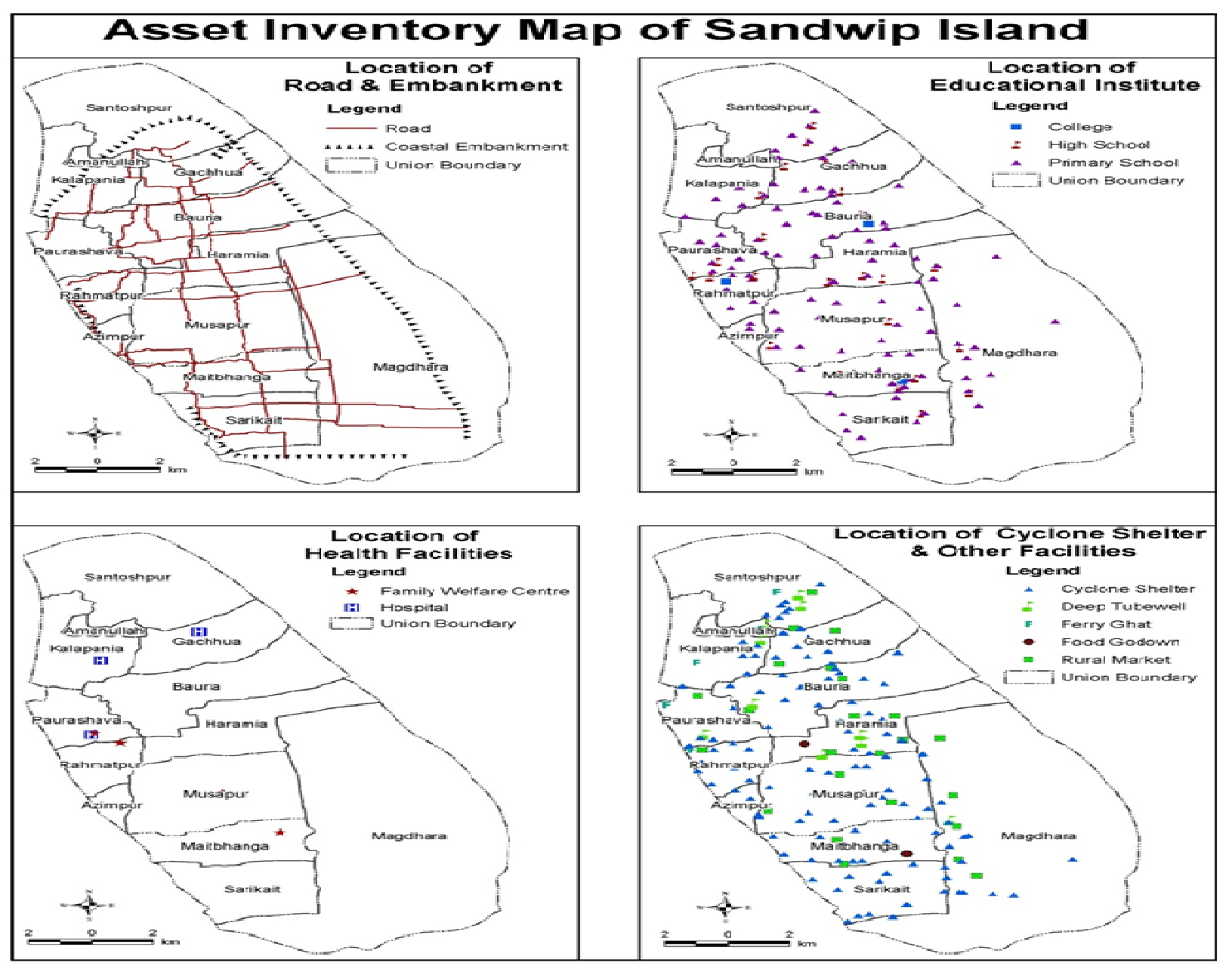

Fig-8: Asset Inventory Map of Sandwip Island 
Table -2: Assigned Percentage of Loss of People for Shelter Units

\begin{tabular}{|l|c|c|c|c|}
\hline \multirow{2}{*}{\multicolumn{1}{c|}{ Shelter Unit Type }} & \multicolumn{2}{c|}{ Percentage loss of People at Day-Time } & \multicolumn{2}{c|}{ Percentage loss of People at Night-Time } \\
\cline { 2 - 5 } & Inundation $\leq \mathbf{0 . 5 m}$ & Inundation > $\mathbf{0 . 5 m}$ & Inundation $\leq \mathbf{0 . 5 m}$ & Inundation > 0.5m \\
\hline Household & $50 \%$ & $70 \%$ & $80 \%$ & $90 \%$ \\
\hline Cyclone Shelter & $20 \%$ & $40 \%$ & $40 \%$ & $60 \%$ \\
\hline Growth Center & $40 \%$ & $60 \%$ & $55 \%$ & $70 \%$ \\
\hline Primary and High Schools & $60 \%$ & $70 \%$ & $70 \%$ & $80 \%$ \\
\hline College & $50 \%$ & $60 \%$ & $60 \%$ & $70 \%$ \\
\hline Madrasa/ Mosque & $60 \%$ & $70 \%$ & $70 \%$ & $80 \%$ \\
\hline $\begin{array}{l}\text { Hospital and Family } \\
\text { Welfare Center }\end{array}$ & $40 \%$ & $60 \%$ & $50 \%$ & $75 \%$ \\
\hline Common Facilities & $50 \%$ & $60 \%$ & $65 \%$ & $75 \%$ \\
\hline
\end{tabular}

Table -3: Summary of Risk Assessment of Sandwip Island

\begin{tabular}{|l|c|c|c|c|}
\hline \multirow{2}{*}{\multicolumn{1}{c|}{ Union }} & \multicolumn{2}{c|}{ Percentage loss of People at Day-Time } & \multicolumn{2}{c|}{ Percentage loss of People at Night-Time } \\
\cline { 2 - 5 } & Inundation $\leq \mathbf{0 . 5 m}$ & Inundation $>\mathbf{0 . 5 m}$ & Inundation $\leq \mathbf{0 . 5 m}$ & Inundation > 0.5m \\
\hline Amanullah & $49.60 \%$ & $69.60 \%$ & $80.00 \%$ & $89.90 \%$ \\
\hline Azimpur & $50.87 \%$ & $68.78 \%$ & $79.80 \%$ & $89.80 \%$ \\
\hline Bauria & $47.90 \%$ & $66.70 \%$ & $79.60 \%$ & $89.69 \%$ \\
\hline Gachhua & $50.45 \%$ & $68.84 \%$ & $79.61 \%$ & $89.71 \%$ \\
\hline Haramia & $49.84 \%$ & $68.33 \%$ & $79.60 \%$ & $89.67 \%$ \\
\hline Kalapania & $47.73 \%$ & $66.28 \%$ & $79.67 \%$ & $89.77 \%$ \\
\hline Magdhara & $47.45 \%$ & $66.19 \%$ & $79.65 \%$ & $89.73 \%$ \\
\hline Maitbhanga & $48.71 \%$ & $66.79 \%$ & $79.61 \%$ & $89.72 \%$ \\
\hline Musapur & $46.96 \%$ & $65.59 \%$ & $79.66 \%$ & $89.75 \%$ \\
\hline Rahmatpur & $49.10 \%$ & $66.89 \%$ & $79.27 \%$ & $89.48 \%$ \\
\hline Santoshpur & $48.26 \%$ & $67.03 \%$ & $79.64 \%$ & $89.72 \%$ \\
\hline Sarikait & $46.32 \%$ & $65.33 \%$ & $79.73 \%$ & $89.79 \%$ \\
\hline Paurashava & $49.49 \%$ & $68.37 \%$ & $79.82 \%$ & $89.88 \%$ \\
\hline
\end{tabular}

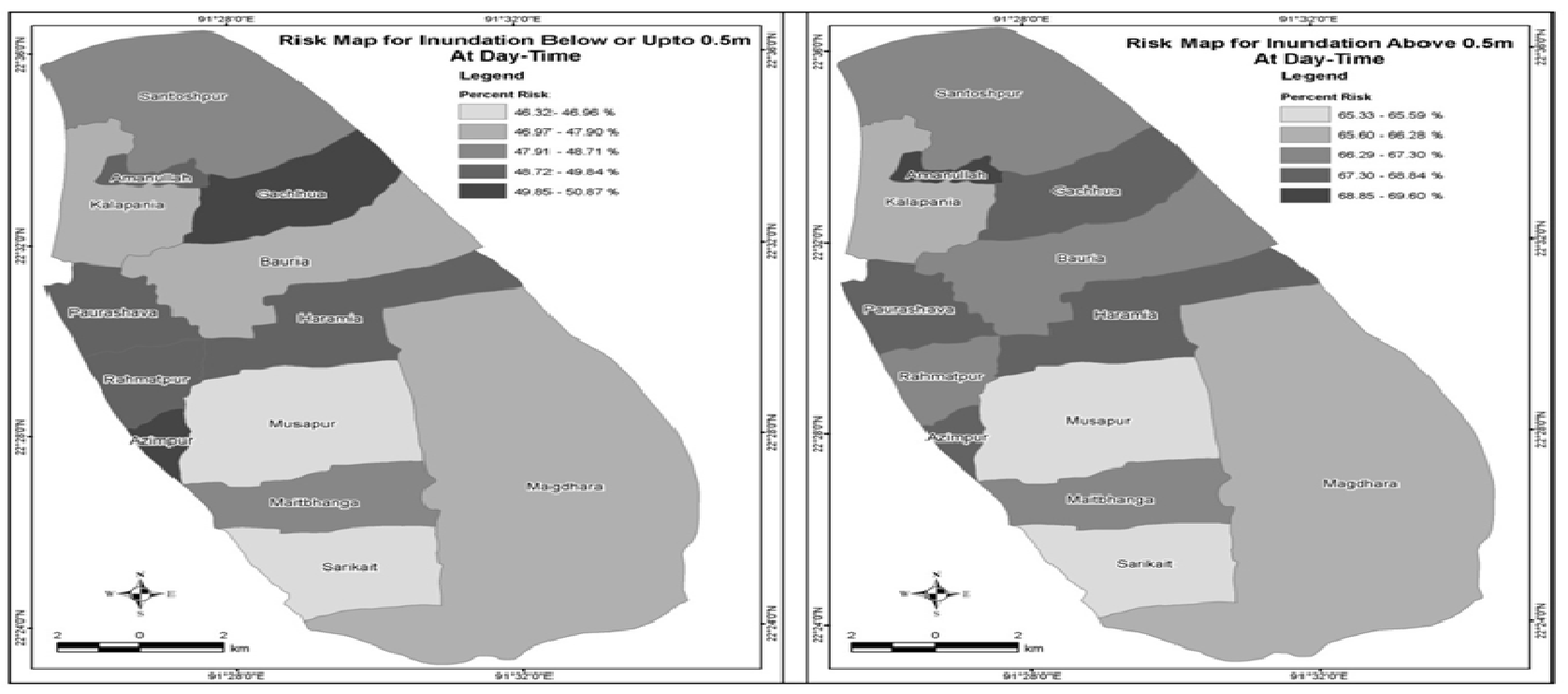

Fig- 9: Risk Map for Day-Time Tsunami (For Inundation $\leq 0.5 \mathrm{~m}$ and Inundation $>0.5 \mathrm{~m}$ ) 


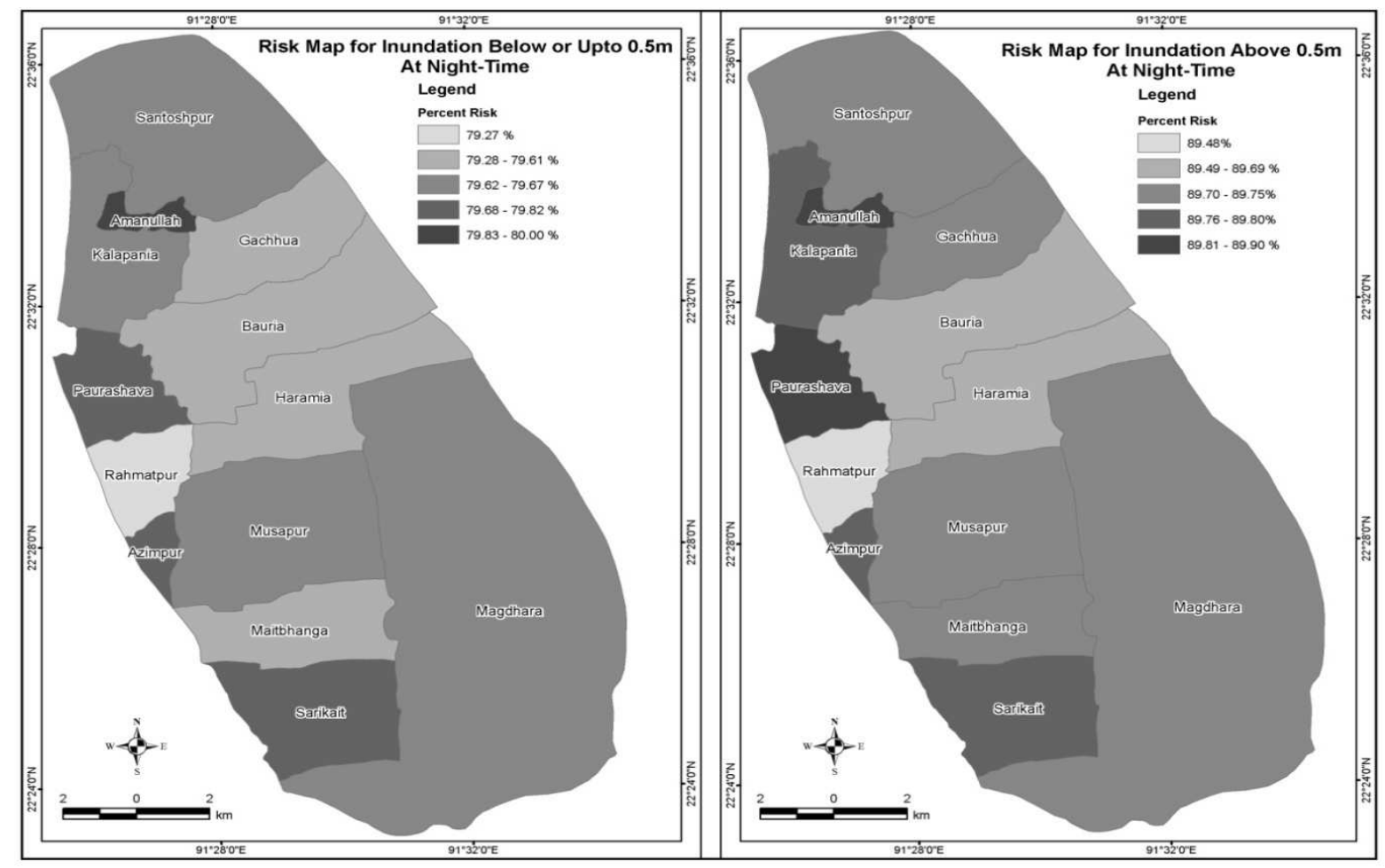

Fig- 10: Risk Map for Night-Time Tsunami (For Inundation $\leq 0.5 \mathrm{~m}$ and Inundation $>0.5 \mathrm{~m}$ )

This will create enormous damage to the life and property. For each union the assigned value of percentage of loss of people are assumed the same for a particular shelter unit. Again, for a night time tsunami the corresponding loss of lives is assumed to be more than a day time tsunami. Table 2 gives an overview of assigned percentage of loss of lives for each type of shelter unit as a part of the assessment of community response to a tsunami.

\subsection{Results of Assessment of Risk}

Assessment of risk combines the outcome of the hazard, vulnerability and community response assessments and portrays the potential risk levels in the corresponding areas. Risk is expressed by the percentage of possible losses of lives for a particular scenario of tsunami. The scenarios that are considered for each union are: i. Inundation below or upto 0.5 $\mathrm{m}$ at day-time. ii. Inundation below or upto $0.5 \mathrm{~m}$ at nighttime. iii. Inundation above $0.5 \mathrm{~m}$ at day-time. iv. Inundation above $0.5 \mathrm{~m}$ at night-time.

The obtained results from risk assessment are given for each union in tabular form (Table 3). Finally risk maps (Figure 9 and Figure 10) are produced for Sandwip Island based on the risks presented in the Table 3.

\section{CONCLUSIONS}

From the results of risk assessment it is evident that a minimum of about 60 percent of people in the shelter units which are susceptible to potential inundation are at risk to lose their lives. With rise of inundation heights, the percentage of possible loss of people also rises accordingly. Again a nighttime tsunami poses more threat to people than a day-time tsunami. For this process, practical facts about the way of life of people in the study area is the main basis of judgment of allocating people in different shelter units as well as percentage of loss of lives in shelter units for different inundation heights and time of tsunami event.

Some key aspects of the results are given below:

i. About $67 \%$ percentage of total area is likely to be inundated under $0.5 \mathrm{~m}$ and $33 \%$ percentage of total area is likely to be inundated above $0.5 \mathrm{~m}$ tsunami waves.

ii. People in the cyclone shelter are likely to be less affected by tsunami while people in households are at high risks to be affected by tsunami wave. It is important to note that at tsunami event people will get hardly any time to evacuate their places and move to cyclone shelter.

iii. Magdhara union is at more risk than other unions if the tsunami wave height is below or upto $0.5 \mathrm{~m}$ or exceeds $0.5 \mathrm{~m}$. 
iv. Sarikait union is at the lowest risk (46.32\%) for inundation below or upto $0.5 \mathrm{~m}$.

v. The aggregated loss in households is high since most of the time women, elderly people and children stay there.

\section{REFERENCES}

[1] BBS (2003), "Bangladesh Statistical Yearbook", Dhaka

[2] CDMP (2008) "Tsunami Vulnerability Assessment of Cox's Bazar District”, Disaster Management Bureau, Ministry of Flood and Disaster Management, Submitted to Government of Peoples Republic of Bangladesh.

[3] Chowdhury, J. R. (1993) "Seismicity in Bangladesh", International Center for Disaster- Mitigation Engineering, Institute of Industrial Science, University of Tokyo.

[4] Cummins, P. R. (2007), "The Potential for Giant Tsunamigenic Earthquake in the Northern Bay of Bengal", Nature 449, 75- 78 (6 September, 2007), doi: 10.1038 /nature06088.

[5] CZPo (2005), "Coastal Zone Policy", Ministry of Water Resources, Government of Peoples Republic of Bangladesh.

[6] Fradin, J. B., Brindell, D (2008), "Witness to Disaster: Tsunamis", Witness to Disaster, Washington D. C., National Geographic Society, pp 42, 43.

[7] Haugen, K., Lovholt, F., Harbitz, C. (2005), "Fundamental Mechanisms for tsunami generation by Submarine Mass Flows in Idealised Geometries". Marine and Petroleum Geology 22: 209-217. doi:10.1016/j.marpetgeo.2004. 10. 016.

[8] Hussaini, T., M., A., Habib, A., Hossain, M., A. (2005), "Multi- Hazard Disaster Reduction in the Coastal Region of Bangladesh". International Symposium Disaster Reduction on Coasts ScientificSustainable- Holistic- Accessible, November 2005, Monash University, Melbourne, Australia.

[9] IOC (2009) "Tsunami Risk Assessment and Mitigation for Indian Ocean", Intergovernmental Oceanographic Commission (IOC), Manual and Guides No. 52, UNESCO, Paris.

[10] Islam (2004), "Where Land Meets the Sea: A Profile of the Coastal Zone of Bangladesh", The University Press Limited, Dhaka.

[11] Margaritondo, G. (2005), "Explaining the Physics of Tsunamis to Undergraduate and Non- Physics Students". European Journal of Physics 26 (3).

[12] Mardiatno, D., Kongko, W., Lavigne, F., Sunarto, Stoetter, J. (2008) "GIS Application for Tsunami Risk Assessment in Cilacap, South Java- Indonesia", International Conference on Tsunami Warning (ICTW) 2008, Bali, Indonesia.

[13] Sarker, N. C. D. (2008), "Tsunami Simulation and Hazard Assessment on the Bangladesh Coast", MEE06088

\section{BIOGRAPHIES}

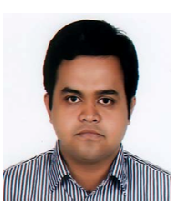

Zaka Uddin Ahmad completed his graduated from Bangladesh University of Engineering and Technology [BUET] at 2011. He is now continuing his M.Sc. in Environmental Engineering at BUET.

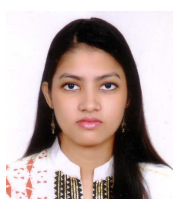

Iftesham Bashar has Completed his M.Sc. in Civil and Structural Engineering from Bangladesh University of Engineering and Technology [BUET] at 2012.

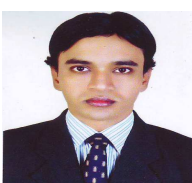

Md. Mostafizur Rahman has completed his graduated from Bangladesh University of Engineering and Technology [BUET] at 2009. $\mathrm{He}$ has good knowledge in Geotechnical Engineering and Environmental Engineering. Now he is continuing his M.Sc in BUET.

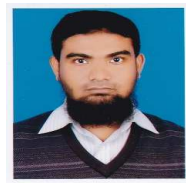

Arifuzzaman joined the University of Information Technology and Sciences as a faculty of Civil Engineering in January, 2013. $\mathrm{He}$ has completed his M.Sc. in Civil and Geotechnical Engineering from Bangladesh University of Engineering and Technology [BUET] at 2011. Author Completed his graduation in Civil Engineering from Rajshahi University of Engineering and Technology in March, 2007. He has ten publishes international journals and eight international conference papers. He has sound knowledge in the field oh Geotechnical and Environmental Engineering. 